\title{
EVALUATION OF A COLORIMETRIC BABESIA BIGEMINA-DNA PROBE WITHIN AN EPIDEMIOLOGICAL SURVEY
}

\author{
JUAN A. RAMOS; JESUS A. ALVAREZ; JULIO V. FIGUEROA*; JOSE SOLIS; ROGER I. \\ RODRIGUEZ**; RUBEN HERNANDEZ; GERALD M. BUENING* \& CARLOS A. VEGA
}

Unidad de Hemoprotozoarios, Cenid-Parasitologia, INIFAP, Apdo. Postal \# 206, Civac. C.P. 62500, Morelos, Mexico *Dept. Vet. Microbiology, College of Veterinary Medicine, UMC, Columbia, MO 65211, USA * Depto. de Parasitologfa, Facultad de Medicina Veterinaria y Zootecnia, UADY, Apdo. Postal \# 116D, Itzimná, C.P. 97100, Yucatán, Mexico

An epidemiological survey was conducted in southeast Mexico, in an effort to establish the serological reactivity and carrier status to Babesia bigemina of an indigenous cattle population. The prevalence was obtained through the Indirect Fluorescent Antibody Test (IFAT), using an in vitro culture-derived $\mathrm{B}$. bigemina antigen. $A$ specific, digoxigenin-coupled, $\sim 6 \mathrm{~Kb} \mathrm{~B}$. bigemina$D N A$ probe $(B B D P)$, was used to indicate the presence of the parasite. Serum samples from 925 animals of all ages, were obtained within the three regions $(I, I I, I I I)$ of the state of Yucatan and tested by IFAT. In addition, whole blood samples drawn from 136 of the same animals of region II were analyzed using the BBDP. Positive IFAT (IFAT+) reactions were observed in 531 sera for a $57 \%$ overall prevalence. Regional values were: $I=157+(56 \%), I I=266+(68 \%)$ and $I I I$ $108+(42 \%)$. Only 32 (23\%) of the blood samples tested with BBDP showed distinctive hybridization signal, in contrast with 100 (73\%) IFAT+ animals. The response distribution for IFAT vs. $B B D P$ was: $+/+23,+/-77,-/+9$ and $-/ 27$ respectively. It was found that the analytical sensitivity of BBDP appears to be low for its utilization in widespread epidemiological surveys. It was considered, however, that the colorimetric probe might be useful to safely detect transmission prone carriers, since it is able to detect parasitemias as low as $0.001 \%$.

Key words: Babesia bigemina - DNA probe - Epidemiology - IFAT

Bovine babesiosis is a world-wide disease of cattle, caused by the intra-erythrocytic protozoan parasites of the genus Babesia, which are transmitted by ticks (McCosker, 1981). In America, only two species have been recognized in cattle, $B$. bovis and $B$. bigemina (Quiroz-Romero, 1984). Animals that recover from infection, remain carriers of the parasite at undetectable levels, and develop a strong immunity against future infections (Mahoney, 1972; Mahoney et al., 1973). Serological procedures used for the diagnosis of babesiosis do not consistently detect carrier animals, nor do they discriminate the cross-reactivity against other related Babesia species. Subclinically infected animals are identified only by inoculation of blood into susceptible cattle. The use of recombinant DNA probes and proper nucleic acid hybridization will eventually have some

Partially financed by USAID prime agreement No. DAN4178-A-00-7056-00. advantages over conventional microscopic, serological and subinoculation techniques. A $B$. bigemina ${ }^{32} \mathrm{P}$-labeled probe, obtained from cloned segments of genomic $B$. bigemina DNA from a Mexican isolate, was recently described and proved to be very sensitive (Buening et al. 1990). However, ${ }^{32}$ P-labeled probes still have several disadvantages for field use because, they would require highly trained personnel, expensive equipment, frequent relabelling and proper disposal facilities. Utilization of a colorimetric procedure would eliminate such difficulties. The development of a colorimetric DNA hybridization method to detect $B$. bigemina, was also reported recently (Figueroa et al., 1990). They informed that the probe was able to detect parasitemias of $0.001 \%$ in $500 \mu \mathrm{l}$ volumes of packed cells. The objectives of the present study were to determine the seroreactivity to $B$. bigemina, by the Indirect Fluorescence Antibody Test, of an open cattle population, to evaluate the applicability of the colorimetric DNA assay in the identification of carrier ani- 
mals, and to compare the two methods, for epidemiological determinations including the Daily Probability Infection rate (Mahoney \& Ross, 1972).

\section{MATERIAL AND METHODS}

Location - The study was conducted in the state of Yucatan, in southeast México, an area considered to be "dry" tropic, with a warm, subhumid climate $A w$ according to Garcia (1976). Yucatan, with a total cattle population of 646,371 heads, is composed of 106 municipalities. According to cattle population density and general management practices, the state was divided into three different regions. Municipalities within the regions were selected at random.

Sample size - Sample size was determined according to the exact populations equation (Daniel, 1982), considering the total number of heads in each region, as the population "N", regardless of age. An error of 0.2 and a confidence level of $95 \%$ were assumed, based on a previous estimation of a $60 \%$ serological prevalence. Figures were then included into five groups, considering their age in months, $\mathrm{A}$ : < $3, \mathrm{~B}: 3$ to $9, \mathrm{C}: 9$ to $18, \mathrm{D}: 18$ to 36 and $\mathrm{E}:>$ 36 months.

Sampling and subsampling - Sampling included the collection of serum from animals of the three regions for the serological test. Subsampling consisted of the collection of whole blood for DNA hybridization from 136 randomly selected animals in region II, simultaneously to the collection of serum.

Sample collection and preparation - Blood was aseptically obtained by venipuncture of the animal's Jugular or tail veins, into evacuated glass tubes (VACUTAINER ${ }^{\mathrm{R}}$, Becton-Dickinson de México, S.A. de C.V.), without anticoagulant. After clotting at room temperature, serum was collected and stored frozen at -20 ${ }^{\circ} \mathrm{C}$ until used. Similar procedure was followed for the collection of whole blood except EDTA was used as anticoagulant. After collection, blood samples were washed three times by centrifugation with TEN buffer $(0.1 \mathrm{M}$ Tris$\mathrm{HCl}, \mathrm{pH} 8.0 ; 0.15 \mathrm{M} \mathrm{NaCl}, 10 \mathrm{mM}$ EDTA); supernate and buffy coat were discarded each time. Packed erythrocytes were stored frozen at $-20^{\circ} \mathrm{C}$ in $500 \mu$ aliquots.
Indirect Fluorescent Antibody Test (IFAT) - It was carried out as reported by Goldman and coworkers (1972), except that antigen slides were prepared using in vitro culture-derived $B$. bigemina "seed" strain (Vega et al., 1985), and submerged in acetone during $30 \mathrm{~min}$, for fixation. Sera were diluted 1:80 in PBS pH 7.2, which is considered the standard diagnostic dilution. FITC-anti bovine IgG was obtained from a commercial source (Cappel Labs. Inc.).

DNA probe (BBDP) - A cloned B. bigemina insert was removed from $\mathrm{pBR} 322$ plasmid vector by digestion of $\mathrm{pBbil} 16$ with restriction endonucleases BamHI and BstEII (Buening et al., 1990). The insert $(\sim 6 \mathrm{~Kb})$ was then purified from plasmid DNA by agarose gel electrophore. sis and electroelution. The insert was labeled by the random-primed incorporation of digoxigenin-deoxyuridine triphosphate (DigdUTP) using a commercially available labeling kit (GENIUS $^{\mathrm{TM}}$, Boehringer Mannheim Biochemicals). After ethanol precipitation and centrifugation at $12,000 \mathrm{xg}$ the probe was diluted in TE buffer $(0.1 \mathrm{M}$ Tris- $\mathrm{HCl}$, pH 8.0, $10 \mathrm{mM}$ EDTA). The concentration of labeled DNA probe was adjusted to $1 \mu \mathrm{g} / \mathrm{ml}$ in hybridization solution 5X SSC (Sambrock et al., 1989) containing: $5 \%(w / v)$ casein from non-fat dry milk, $0.1 \%(w / v)$ lauroylsarcosine, $0.02 \%(w /$ v) SDS and $50 \%(\mathrm{v} / \mathrm{v})$ deionized formamide, and stored at $-20{ }^{\circ} \mathrm{C}$ until used.

Preparation of Target DNA - Erythrocyte samples $(500 \mu \mathrm{l})$ were freeze/thawed twice and washed three times with TE buffer by centrifugation at $12,000 \mathrm{xg}$ for $10 \mathrm{~min}$. The supernatant was carefully removed and the remaining pellets were resuspended in $200 \mu \mathrm{l}$ of TE buffer containing $0.5 \%$ Triton $X-100(\mathrm{v} / \mathrm{v})$ and 400 $\mu \mathrm{g} / \mathrm{ml}$ Proteinase-K. Suspensions were then incubated at $65^{\circ} \mathrm{C}$ for $2 \mathrm{~h}$ and centrifuged once at $12,000 \mathrm{xg}$ for $10 \mathrm{~min}$. at room temperature. Lysate supernatants were processed for DNA purification using a commercially available silica matrix (GENECLEAN ${ }^{\mathrm{R}}$ Kit, BIO 101, Inc.). Eluted supernatants were spotted in 100 $\mu l$ volumes onto nylon membrane filters (NYTRAN ${ }^{\text {TM }}$ modified 66, Schleicher \& Schüell, Inc.), using a dot-blot apparatus.

\section{Dot-Blot hybridization and detection -} Samples, blotted on the filters, were denatured with a $0.5 \mathrm{~N} \mathrm{NaOH}$ solution with $1.5 \mathrm{M} \mathrm{NaCl}$, for $15 \mathrm{~min}$. at $37{ }^{\circ} \mathrm{C}$, neutralized with $0.5 \mathrm{M}$ Tris- $\mathrm{HCl}$ solution with $1.5 \mathrm{M} \mathrm{NaCl}$ and baked, as described elsewere (Sambrock et al., 1989). 
Filters were then prehybridized by submersion for $2 \mathrm{~h}$ at $42{ }^{\circ} \mathrm{C}$ with hybridization solution. The solution was replaced with boiled hybridization solution containing the denatured digoxigenin-labeled BBDP and incubated overnight at $42{ }^{\circ} \mathrm{C}$. Filters were washed two times at room temperature with $2 \mathrm{x}$ SSC containing $0.01 \%(w / v)$ SDS, and then washed two more times at $65^{\circ} \mathrm{C}$ with solution $0.1 \times$ SSC containing $0.1 \%(\mathrm{w} / \mathrm{v})$ SDS. Filters were used directly for immunological detection of DNA hybrids by following the procedure described in the labeling and detection kit, already mentioned (GENIUS ${ }^{\text {TM }}$ ). Positive hybridization signal was identified by a purple-blue spot on the white filter's background.

\section{RESULTS}

Reactivity to $B$. bigemina was observed in both serological and DNA hybridization tests used in the study. Estimation of the sample size indicated that a total of 942 samples was sufficient for prevalence determination by serology; however, since the study was oriented for regions, the total number of serum samples collected and analized was 925 . The number of samples collected per region was: I 277, II 391 and III 257.

The positive responses in IFAT were 157 $(56.6 \%), 266(68.0 \%)$ and $108(42.0 \%)$ for regions I, II and III, respectively. The total prevalence for the state of Yucatan was 57.4\%. The serological reactivity obtained in the three regions and considering the different age groups is summarized in Table I. Subsampling in region II, which included the selection of 136 paired samples, depicted a similar serological prevalence value of $73.5 \%$ (100 positive sera). The Figure shows that the number of serologically positive animals increased progressively with age, with the exception of the groups composed of younger animals ( $<9$ months).

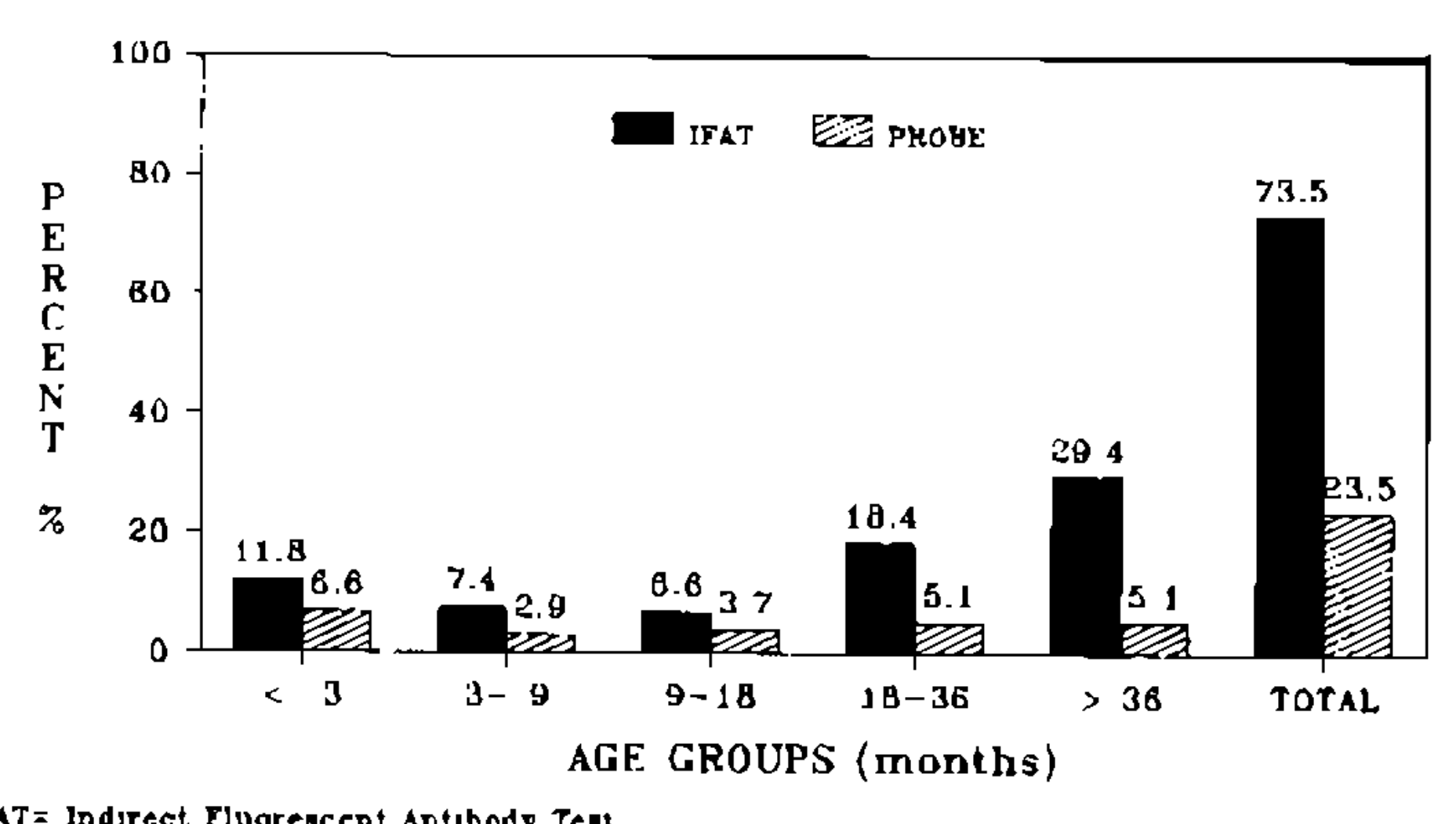
PROBE= Colorimetrece Babesia begemeste Recombinat DNA-Probe

Comparative responses of cattle to two different tests for the identification of Babesia bigemina carrier animals.

On the other hand, positive hybridization signals were observed only in 32 samples (23.5\% prevalence). The number of positive samples increased with age, except in the younger animals $(<3$ months) which showed the highest \% reactivity. Animal's response distribution for IFAT / BBDP was as follows: $+/+23,+/-77,-1+9$ and $-1-27$. The response distribution to both tests according to the age groups is shown in Table II. The number of IFAT positive reactant animals was always higher than that of BBDP positive animals, regardless of the age group. A comparison of the reactivity percentage between the two tests appears in Figure.

TABLE I

Seroreactivity to Babesia bigemina by the Indirect Fluorescent Antibody Test of cattle sera from the State of Yucatan, México, distributed by region and groups of age in months

\begin{tabular}{|c|c|c|c|c|c|c|c|c|c|c|c|c|}
\hline \multirow[b]{2}{*}{ Age groups } & \multicolumn{3}{|c|}{ Region I } & \multicolumn{3}{|c|}{ Region II } & \multicolumn{3}{|c|}{ Region III } & \multicolumn{3}{|c|}{ State } \\
\hline & Pos. & Total & $\%$ & Pos. & Total & $\%$ & Pos. & Total & $\%$ & Pos. & Total & $\%$ \\
\hline$<3$ & 5 & 19 & 26.32 & 20 & 42 & 47.62 & 15 & 44 & 34.09 & 40 & 105 & 38.10 \\
\hline $3-9$ & 18 & 49 & 36.73 & 51 & 84 & 60.71 & 12 & 41 & 29.27 & 81 & 174 & 46.55 \\
\hline $9-18$ & 17 & 28 & 60.71 & 56 & 66 & 84.85 & 40 & 88 & 45.45 & 113 & 182 & 62.09 \\
\hline $18-3622$ & 31 & 70.97 & 43 & 53 & 81.13 & 15 & 26 & 57.69 & 80 & 110 & 72.73 & \\
\hline$>36$ & 95 & 150 & 63.33 & 96 & 146 & 65.75 & 26 & 58 & 44.83 & 217 & 354 & 61.30 \\
\hline Total & 157 & 277 & 56.68 & 266 & 391 & 68.03 & 108 & 257 & 42.02 & 531 & 925 & 57.41 \\
\hline
\end{tabular}

Pos. $=$ positive 
TABLE II

Response distribution to Babesia bigemina of paired serum and blood samples of cattle by age in months, respectively tested by the Indirect Fluorescent Antibody Test and a DNA hybridization assay with a specific, recombinant, colorimetric probe

\begin{tabular}{|c|c|c|c|c|c|}
\hline \multirow[b]{2}{*}{ Age group } & \multicolumn{5}{|c|}{ IFAT/probe } \\
\hline & Pos. / Pos. & Pos. / Neg. & Neg. / Pos. & Neg. / Neg. & Total \\
\hline$<3$ & 3 & 13 & 6 & 8 & 30 \\
\hline $3-9$ & 3 & 7 & 1 & 4 & 15 \\
\hline $9-18$ & 4 & 5 & 1 & 2 & 12 \\
\hline $18-36$ & 7 & 18 & 0 & 0 & 25 \\
\hline$>36$ & 6 & 34 & 1 & 13 & 54 \\
\hline Total & 23 & $n$ & 9 & 27 & 136 \\
\hline$\%$ & 17 & 57 & 7 & 20 & 100 \\
\hline
\end{tabular}

Pos. = positive; Neg. = negative

When results were analized to determine the Daily Probability Infection (DPI) rate adjusted to 9 months of age, it was found that by using IFAT, DPI was 0.0147 and for BBDP, DPI was 0.0029 .

\section{DISCUSSION}

It was observed that the determination of seroreactivity to $B$. bigemina by IFAT and the identification of carrier animals by DNA hybridization, using a safe, colorimetric BBDP, are useful tools for the study of babesiosis.

The results showed clearly that the prevalences were consistently different in the regions of the state, basically due to different management practices. In region I, milk production is more abundant, sanitary restrictions are more easily applied, and cattle owners are more concerned with the application of tick control methods. Also, animals are maintained under semi-intensive conditions, thus partly reducing the contact with ticks. The highest prevalence rate of $68 \%$ was observed in region II, where meat production is the most important economical activity. Cattle is raised under extensive conditions, basically grazing in the open field. In this situation, all ecological factors favour the development of the biological vector and the extent of contact among hosts and parasites. A similar serological survey, carried out in region II ten years ago (Ponce, 1979), showed a $69.0 \%$ prevalence, which is similar to the one obtained in this investigation. This information may suggest that, whether or not any manage- ment practices were introduced in this region with the purpose of improving the health condition of the animals, there has been very little impact on the control of bovine babesiosis. Also, cattle owners have not, perhaps, properly applied the tick control programs proposed by animal health officials or Veterinary practitioners. On the other hand, this situation also remarks the advantages of the enzootically stable situation in this region, restraining producers from introducing changes in their management practices. Livestock production in region III is considered an activity secondary to growing crops. This condition may impose certain restrictions on the development of the tick vector as is reflected in the lowest prevalence value of $42 \%$. The overall serological prevalence of $57.4 \%$ for the entire state of Yucatan, with a value close to the $60 \%$ assumed at the beginning of the study, confirmed the endemic status of bovine babesiosis.

The use of a BBDP in a regular laboratory manifested its safe handling, since it presented no health hazzard for the personnel involved, nor special equipment was required for its utilization.

The usefulness of the probe was demonstrated by identifying the presence of the parasite in the youngest animals. It has been generally accepted that younger animals show higher serological reactivity values, due to colostral antibodies from their mothers (AlvarezMartínez, 1989). This work indicates that high antibody values in animals less than 3 months 
of age, could also be induced by an actively acquired immunity due to infection. The fact that a clinically inapparent infection is present in animals of such age, also reinforces the concept of inverse age resistance in bovine babesiosis (Christensson, 1989).

The colorimetric BBDP sensitivity may appear to be low when compared to the results obtained by IFAT. However, BBDP responses surely indicate that only a small proportion of the animals in the field can be considered as truly infected. This infection may suppose a significant number of parasites in the blood stream, which although undetected by microscopic observation, may well be ingested by ticks, thus perpetuating the life cycle. One must be aware of the concept of "carrier-reservoir" (Wagner, Gale; Texas A\&M University: personal communication), which implies that only a small number of carrier animals - those sustaining a threshold parasitemia - play an active role in the transmission of Babesia spp. In addition, the positive identification of $B$. bigemina infected animals within a population, facilitates the decision-making process by indicating, mainly, the species of Babesia that is in fact present in the herd. Therefore, this information becomes extremely useful when selecting the most adequate procedure for immunization in order to specifically protect susceptible or naïve cattle.

In agreement with the above mentioned observations, serology derived data was used for the determination of the 0.0147 DPI rate within the subsampling of region II, indicating a condition of enzootic stability. In contrast, when the epidemiological prediction model (Mahoney \& Ross, 1972) is applied to results obtained from the DNA hybridization assay the determined 0.0029 DPI rate reflected a deceptive condition of enzootic instability. Thus, one must consider that, in this instance the given limited analytical sensitivity shown by the DNA-based assay imposed a restriction on the applicability of this model.

It is recommended that future studies of this type should include a more sensitive reagent or, perhaps, a newer methodology such as the Polymerase Chain Reaction (PCR), in which the target DNA may be amplified many times before being detected by conventional hybridization techniques.

\section{REFERENCES}

ALVAREZ-MARTINEZ, J.A., 1989. Inmunidad humoral en la anaplasmosis y babesiosis bovinas en becerros mantenidos en una zona endémica. Tesis, Maestria en Ciencias, FMVZ, Universidad Nacional Autónoma de México. México D.F., 118 p.

BUENING, G.M.; BARBET, A.; MYLER, P.; MAHAN, S.; NENE, V. \& McGUIRRE, T.C., 1990. Characterization of a repetitive DNA probe for Babesia bigemina. Vet. Parasitol., 36: 11-20.

CHRISTENSSON, D.A., 1989. Inverse age resistance to experimental Babesia divergens infection in cattle. Acta Vet. Scand., 30: 453-464.

DANIEL, W.W., 1989. Bioestadistica, base para el análisis de las ciencias de la salud. $3^{\mathrm{a}}$ ed. Editorial Limusa, México D.F., 667 p.

FIGUEROA, J.; BUENING, G.M. \& ALVAREZ J.A., 1990. Uso de una sonda de ADN para el diagnóstico de Babesia bigemina. p. 102-104. In Memorias, Reunión Nacional de Investigación Pecuaria. Nov. 12-16, Villahermosa, México.

GARCIA, E., 1976. Modificaciones al sistema de clasificaión climática de Köeppen (para adaptarlo a las condiciones de la República Mexicana). Instituto de Geografia, UNAM. México D.F., 29 p.

GOLDMAN, M.; PIPANO, E. \& ROSEMBERG, A.S., 1972. Fluorescent antibody tests for Babesia bigemina and $B$. berbera. Res. Vet., Sci., 13: 77-81.

MAHONEY, D.F., 1972. Immune response to hemoprotozoa: II. Babesia spp. p. 301-341. In E.J.L. Soulsby, Immunity to animal parasites. Academic Press, N.Y.

MAHONEY, D.F. \& ROSS, D.R, 1972. Epizootiological factors in the control of bovine babesiosis. Aust. Vet. J., 48: 292-298.

MAHONEY, D.F.; WRIGHT, I.G. \& MIRRE, G.B., 1973. Bovine babesiosis: The persistence of immunity to Babesia argentina and $B$. bigemina in calves (Bos taurus) after naturally acquired infection. Ann Trop. Med. Parasitol., 67: 197-203.

McCOSKER, G.P., 1981. The global importance of babesiosis, p. 1-24. In M., Ristic \& J.P. Kreier, Babesiosis. Academic Press, New York.

PONCE, L.I., 1979. Determinación de la probabilidad diaria de infección de Babesia spp. de un hato de bovinos en el C.E.P. de Tizimín, Yucatán. Tesis, FMVZ, Universidad Nacional Autónoma de México. México D.F., 47p.

QUIROZ-ROMERO, H., 1984. Parasitologia y enfermedades parasitarias de animáles domésticos. Editorial Limusa, México D.F., 876 p.

SAMBROCK, J. FRITSCH, E.F. \& MANIATIS, T., 1989. Molecular cloning. A laboratory manual. 2nd ed. Cold Spring Harbor Lab., New York.

VEGA, C.A.; BUENING, G.M.; GREEN, T.J. \& CARSON, C.A., 1985. In vitro cultivation of Babesia bigemina. Am. J. Vet. Res:, 46: 416-420. 